\title{
Windmills as the Forgotten Cultural Heritage Returning to Favour
}

According to Jerzy Adamczewski, windmills are associated with "ruin, frequently a damaged building robbed of its wings" (Adamczewski 2005: 5). With this image in mind, we should ask ourselves a few questions: Why do they look like that? What activities have led to this situation? Or perhaps there have been no activities? What should we do to give windmills a second life? There are many answers to these questions; not all of them are simple, and some are even very controversial.

Wooden architecture is extremely difficult to preserve. The difficulties include: non-durable materials, susceptibility to damage, exposure to the destructive effects of insects, and many other factors. In many cases, the poor technical condition of the buildings resulting from their age and wear does not allow to preserve their original function or to convert them for functional purposes, at the same time complying with the technical requirements (Grabski 20I2: Io). Whenever an idea emerges to change the function of a windmill, there is a problem with obtaining adequate financial resources for its conservation and restoration, and for the conversion work. And after the conversion, the building frequently loses some of its value (Tajchman 1999: 363-382; Gosztyła, Pasztor 2013: 67-68). Another problem is the fact that windmills are located in distant places, far from urban centres. Their conversion would most probably require relocation to a more convenient place, however, this would entail the need for additional financial resources.

Today, it is impossible for windmills to serve their original purpose. There are no specialists earning their living as millers/windmillers, which are dying trades. There is also nowhere to learn this trade. Millers are usually of advanced age, so they would not be able to cope with the hard work in a windmill, and they have no successors. Heirs to windmills have no plans for them, 
and they use them as storerooms for fodder, tools, or firewood (Pawlik 1984: I53). Deserted buildings degrade very rapidly, which is frequently precipitated by acts of vandalism. They have no proper documentation, which is why they are forgotten and disappear (Tajchman 2007: 35-57; Nowakowski 2006: I).

Privately owned windmills are usually left unsupervised. The owners do not have sufficient financial resources to conduct conservation work, and they do not know where to find sources of funding for the restoration of their property. However, the greatest problem is that they see no point in conducting such work. Investments in objects that have long been unprofitable seem unwise, while the windmills themselves become useless (Stefański 1969: 29). They were of importance when they provided goods to the local market. The owners' behaviour clearly indicates that they do not understand the value of these historic buildings. Windmills are perceived from a practical perspective and not as sources of knowledge of the technological development and production methods, or as an element of the Polish landscape (Jasiuk 1965: 25). Only a few of them have been renovated on the initiative and using the resources of their owners, but even though the reason for renovation was an attempt to preserve the buildings, it still is unauthorised construction. Examples of such buildings include: a paltrok mill in Orle (Kujawy-Pomerania Province) and a mill of the same type in Pomiany (Kujawy-Pomerania

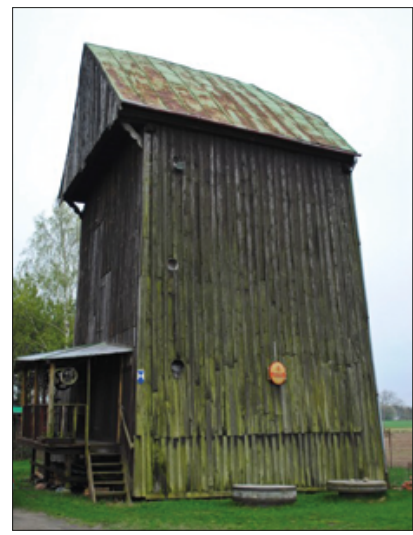

Fig. 1. A paltrok mill in Orle (Kujawsko-Pomorskie Province) (source: http://www.radziejow. $\mathrm{pl} / 372$,gmina-topolka.html, access 4 VI 2017). Province). They do not have the required documentation or a conservation plan based on previous research ${ }^{\mathrm{I}}$.

An advantage of the work performed is definitely the fact that it contributed to the extending of the mills' life, and that the renovation was performed by millers who know well the unique character of such buildings. In case a miller is not able to perform the renovation work himself, he supervises the work. The construction work performed, however, frequently obliterates the traces of previous renovation, and so the mill loses its value. The new elements installed are not authentic, and in some cases, there are no attempts whatsoever to recreate them using the original technology and tools.

I The necessity to prepare conservation documentation is described in detail by Maciej Prarat, an experienced researcher in the field of wooden architecture (Prarat 20I5: 183-210). 
There are also windmills located on arable land, hindering agricultural work (Rouba 2000: 49). If such a windmill is listed, the owner will not obtain a permit for its demolition. Then, a fire may break out, effectively eliminating the windmill from the local landscape.

Another great problem is lack of interest on the part of provincial conservator-restorers who sometimes even do not know the condition of the windmills located in their area, while destroyed windmills are still listed in the Register of Historic Monuments. Neither the owners of the mills nor conservator-restorers know how to use them. This was proved by a survey conducted at the end of the I970s in which provincial conservator-restorers were asked about the condition and plans for conversion and further protection of windmills and mills located in their respective Provinces. Many of them failed to answer this question, while others only provided some data and ideas how to use the buildings, which should be viewed critically. They mentioned, among other things, conversion into a storehouse for tourist equipment, a country club, or a Scouts Chamber, and the use for tourist purposes (Uszyński 1978: 36). As it can be clearly seen, none of the ideas assumed preservation of the equipment of these buildings. Quite the opposite, the activities listed would require tidying up the interior of the mills and creating more floor space. The architectural shape of a windmill without its typical furnishings gives rise to some doubts as to the name of the building and its value.

In the former Konin Province, also in the I970s, there were plans to concentrate the preserved windmills in one place and to operate them (Uszyński 1978: 35). However, they have never been implemented. Provincial conservator-restorers do not even ensure that the listed windmills have appropriate labels informing about legal protection.

In 2003, the Monuments Preservation Department of the Ministry of Culture and National Heritage ordered provincial conservator-restorers to verify the data on historical monuments in Poland. The information gathered was then used to draw up a report on the condition of historical monuments in Poland. The data delivered to the National Heritage Board of Poland (before January I, 20II, called the National Centre for Research and Documentation of Monuments) was very diverse and incomplete, with numerous errors and inaccuracies. Based on the comparison of different groups of historical monuments it can be said that industrial monuments are in a very poor and constantly deteriorating condition. The technical monuments mentioned also included windmills. The report emphasises that the reasons for the increasing threat to industrial buildings are the loss of their technological functions and difficulties with their conversion for other purposes, which can also be said about windmills. Only a few of the buildings have a good chance of getting converted. 
Tab. 1. A list of windmills entered into the Register of Historical Monuments according to their types and locations (Provinces) (own work based on the analysis of the Register of Historical Monuments of the National Heritage Board of Poland, source: http://www.nid.pl/pl/Informacje_ogolne/Zabytki_w_Polsce/rejestr-zabytkow/zestawienia-zabytkow-nieruchomych/Raport_o_stanie_zabytkow_2004.pdf, access 20 VI 2017).

\begin{tabular}{|c|c|c|c|c|c|}
\hline \multicolumn{6}{|c|}{ The number of windmills entered into the Register of Historical Monuments } \\
\hline Voivodeship & Post mills & $\begin{array}{l}\text { Paltrok } \\
\text { mills }\end{array}$ & $\begin{array}{c}\text { Dutch } \\
\text { windmills }\end{array}$ & $\begin{array}{c}\text { Unidentified } \\
\text { type }\end{array}$ & Total \\
\hline LOWER SILESIA & 5 & I & II & 2 & 19 \\
\hline KUYAVIAN-POMERANIAN & 5 & 2 & 2 & - & 9 \\
\hline LUBLIN VOIVODESHIP & 8 & I & I & - & IO \\
\hline LUBUSZ VOIVODESHIP & IO & - & 2 & 2 & I4 \\
\hline LODZKIE & 9 & - & - & I & IO \\
\hline LESSER POLAND & - & - & - & - & $\mathrm{O}$ \\
\hline MASOVIAN & II & 2 & 6 & I & 20 \\
\hline MASOVIAN (WARSAW) & - & - & - & - & O \\
\hline OPOLE VOIVODESHIP & 2 & - & 4 & - & 6 \\
\hline SUBCARPATHIAN & 6 & I & - & - & 7 \\
\hline PODLASKIE VOIVODESHIP & IO & 2 & $\mathrm{I} 2$ & I & 25 \\
\hline POMERANIAN & I & - & 6 & - & 7 \\
\hline SILESIA & - & - & - & - & o \\
\hline ŚWIĘTOKRZYSKIE VOIVODESHIP & I & - & 2 & - & 3 \\
\hline WARMIAN-MASURIAN & I & I & 7 & 2 & II \\
\hline GREATER POLAND & $7 \mathrm{I}$ & 7 & 6 & 4 & 88 \\
\hline WEST POMERANIAN & 3 & - & IO & - & 13 \\
\hline TOTAL & I 43 & I7 & 69 & I3 & 242 \\
\hline
\end{tabular}

According to the report, mills and windmills are among those industrial and technological monuments that are most likely to get destroyed because they are 'unnecessary' and their deterioration level is considerable. These wooden structures require expenditure on renovation that is incommensurate with the profit on their use.

One of the most urgent tasks the conservation services are faced with is thus the straightening out of the Register of Historical Monument, meaning 
the removal of non-existent objects and verification of the record sheets from the r 1970 and the 1980s. An example can be the record sheet of the paltrok mill in Sowa kept in the the Konin Branch of the Provincial Office of Monument Preservation in Poznań. The sheet contains a description and drawings of a random paltrok mill. The drawings do not correspond with the actual state of the monument. It can be said that the author included data of a different mill believing that all windmills of this type have a similar structure. There are some analogies, however, the buildings are not identical. The structure of paltrok mills can differ in terms of the number of intermediate columns, the arrangement and the number of stays, and the number of girts in each of the windmill's walls.

Windmills located in open-air museums are faced with slightly different problems. The first open-air museums were established in Poland as early as at the beginning of the $2 \mathrm{O}^{\text {th }}$ century. They developed after the Second World War, when the condition of folk architecture deteriorated considerably, with wooden industrial architecture having suffered the most damage (Kudła 1969: 26). In the 1950s, specialists called for the in situ protection of as many buildings as possible, however, in many cases the constantly deteriorating condition made it impossible. Preservation of monuments in their original locations was only possible after a new use had been found for them, which was not easy (Ptaśnik 1969: 7). Thus, the most valuable buildings were relocated to open-air museums, and 'the most valuable' meant that they met certain criteria. They had to be of great significance as technical monuments and to a given region (Kraszewska-Sikorska 2008: 215). Their condition also played an important role. A windmill in a good or very good condition would be put first on the list of buildings to be relocated to an open-air museum. Very old mills could not be omitted due to their historical value. Buildings selected for relocation had to have the original equipment and as few as possible accumulated structural changes (Jasiuk 1965: 26). In consequence, the most valuable windmills were those in which all integrally connected technical and architectural elements were preserved in the original form or with only a few modernisation or conversion changes (Pawlik 1984: 164). These aspects increased their value considerably and lowered the implementation costs of the open-air museum (Uszyński 1978: 34; Święch 1986: 184).

The state of preservation was less significant in the case of windmills dating back to earlier times and including unique structural or technological solutions. This had a negative effect on the survival of much younger windmills which frequently had no proper protection, and so they soon fell into ruin. Naturally, during the penetration testing conducted by ethnographers, abridged documentation for each of the windmills was drawn up. However, the very word 
'abridged' indicates that the documentation failed to include many important aspects. What mattered a lot was the usefulness of the windmill in an open-air museum as it had to be adjusted to economic and social conditions.

The very idea of relocation raises some doubts. Its aim is to relocate a building to an open-air museum, to provide it with conservator's protection, and to make it available to visitors. However, relocation deprives it of its natural surroundings, and the original landscape against which a windmill used to function gets impoverished. In Poland, there are only a few open-air museums established in situ. All those displaying windmills were created in designated areas, which means that each of the windmills had to be relocated. Open-air museums do attempt to recreate the natural environment, however, it is manmade. Relocated windmills are not always exhibited in a proper manner. In many cases, the former lie of the land and location relative to other buildings are not taken into consideration. According to Jerzy Czajkowski, windmills frequently only supplement the exhibition of the open-air museum (Czajkowski 200I: 15). Displaying them against a complex of other buildings and arranging them on a limited area do not fully render their true nature. An example of such an exhibition is the paltrok mill in the Museum of Folk Architecture in Sanok. It received much free space, however, it is also surrounded with a few random buildings. On a flat area around it, there is a school and a homestead with grazing goats (as of July 2015). Had the windmill been located like this when it was used, it would not have been able to catch the wind that powered it.

Windmills relocated to open-air museums are to serve as tourist attractions. Thanks to the conservator's protection they are provided with they can survive, while making them available to visitors upholds tradition and shows the landscape of the villages of old. Attending exhibitions teaches visitors how to think in historical terms, develops social sensitivity, and heightens the aesthetic sense (Midura 1979: 47). Exhibitions in open-air museums ensure wooden mills historical continuity. They offer young people an opportunity to learn something, while for the elderly they are sentimental journeys into the past (Uszyńska 2009: 73).

Only a few of the windmills found in open-air museums today are used, even though they are fully operational. An excellent example is the Ethnographic Park in Olsztynek, which has four fully operational windmills. However, only one of them - a post-frame structure - has ever been operated (Kozłowski 2oro: IV-V). In the whole country, there are two paltrok mills that are sometimes used, but they can only be seen at work a few times a year on holidays and during festivities. The paltrok mill in the Upper Silesian Ethnographic Park in Chorzów was first operated in 2014, while the paltrok 
mill in the Ethnographic Park in Tokarnia is started up once a year on the Bread Day. The mill is prepared to work and used because it has to be shown to a group of visitors.

I believe that craftsmen's workshops operating in open-air museums and the use of industrial equipment should not be treated as shows for an audience. They should be production facilities aimed at business activity, self-sufficient in financial terms, or even generating profit for the museum. However, it should be ensured that the profits do not become more important than the educational purposes open-air museums are to serve.

Foreign exhibitions include many living molinological open-air museums that can be visited while the windmills are at work. There is an open-air museum in Etar, Bulgaria, with working watermills and windmills. They work continuously, servicing the local population, and the profit is a part of the museum's budget. The situation is similar in Zaan in the Netherlands, where windmills relocated from different places serve their original purpose, and the visitors can see millers at work. The mills are open to tourists, without any fees. Thus, the original function of these objects is preserved. The goods produced by the windmills are sold, while the profits go towards the budget of the museum. In Poland, the open-air museum in Chorzów sells flour produced by a windmill. However, it is not intended for consumption, and it only serves demonstration purposes.

The way windmills are shown, directly presenting highly-developed technological and structural solutions, teaches respect for the work of millers and tradition. And thanks to continuing tradition, there is a chance of preserving the dying trades. This form of using windmills complies with the ICOM Declaration from 1972, which introduced management forms presenting production processes called living workshops (Reinfuss 1976: 7).

All buildings placed in an open-air museum are under constant conservator's protection. After being relocated to the museum, they are subject to conservation and renovation work. This is justified, however, the effects of such work may raise some doubts. The use of agents strengthening construction materials interferes in the authentic substance. Each conservation procedure obliterates the traces of the previous work, rendering its proper interpretation impossible (Prarat 20II: IOI). In the case of buildings in open-air museums, replacement of damaged elements is a matter of controversy. Despite recommendations that old wood should be used when replacing elements, it is not always available. New elements are prepared and aged so that the aesthetic value is not lowered. Thus, proper reception is distorted. These elements, even though they are not original, they appear to be so (Kowaleski 1972: 437). 
In the process of selecting windmills for open-air museums, factors taken into consideration include the state of preservation, the authenticity of the equipment, and the uniqueness of solutions, however, during conservation work, these aspects are pushed into the background. Despite assumptions and assurances of open-air museums about constant control of the state of preservation of windmills and other buildings, the reality is sometimes different. This is particularly clear in the case of the windmill from Grzawa, converted from a post mill into a paltrok mill, which can now be found in the Upper Silesian Ethnographic Park in Chorzów. The windmill was brought to the museum in the 196os. This was also when the construction material was strengthened with proper agents. The documentation from 1990 indicates that the windmill required complete renovation at the time. Its disassembled wings were deformed and rotten. The mechanisms, which had not been used for a long time, were to a large extent rusted, and the structural elements had areas of dampness. This means that the museum had not made every effort to protect the mill from damage, even though it had been obligated to do so. In 2008 , the degradation of the windmill continued. It is impossible to operate the mill because its wings were incorrectly reconstructed during the repair. Structural elements are fungus-infested and there are many pieces missing. Only in 2013, when the condition of the windmill became a threat to the visitors and many of the elements were beyond recovery, did the Ethnographic Park decide to carry out revitalisation, which was to restore the original function of the mill and to start up the mechanism. The considerable extent of degradation of the windmill made it necessary to replace many authentic elements with new ones. Thus, the cost of the work automatically increased (Klajmon, Liboska 20I3: I-IO). The revitalisation programme indicates that for many years the windmill was closed to visitors, and that the Ethnographic Park did not plan to start it up even though it was fully operational right after the relocation. Negligence on the part of the museum contributed to a considerable decrease in its condition. As a result of the revitalisation, many values originally possessed by the windmill were lost, and the renovation made the correct reception impossible. A great advantage is that the windmill was finally started up and it produces flour that can be bought in the museum's shop.

Apart from all the above problems with protection, preservation and conservation of windmills, there is also a list of good practices, mostly containing foreign examples. It is worth presenting here briefly the activities undertaken in the Netherlands. As early as in the I920s, when there were still many windmills, the Netherlands started to work towards their preservation as tools that were still in use. On May 15, 1923, De Molen Hollandsche association was founded, 
with the main aim to promote knowledge of windmills, generate interest in this field, preserve windmills and their environment in as good a condition as possible, maintain their original function, and find people interested in taking care of them. Members of the association were aware of the fact that windmills had played a major role in the economy of the Netherlands and were essential elements of the Dutch urban and rural landscape (Stokhuyzen 20IO: 2). The development of windmills was supported so that maintaining them was profitable to millers. The value of mills was promoted in press articles, and an attempt was made to change the law in order to protect them. However, most of these plans were not implemented. In the 1970s, the basic goal established was to stop the decrease in the number of windmills and to preserve them as typical elements of the Dutch landscape. Different associations were established to protect the wind milling industry and to gather financial resources to be allocated for their restoration. Today, the aim is to preserve windmills in as good a condition as possible and, whenever possible, to restore their original function. Similar activities are conducted in France and Germany (Gola 2007: 30-42).

A very important step towards the preservation and protection of windmills is the activity of the Molinological Society in Portugal. In 1962, the Portuguese Society of Friends of Windmills and Watermills came up with an idea to organise an international conference devoted to the issue of molinology. It took three years to organise it. In late September and early October 1965 , participants of the $\mathrm{I}^{\mathrm{st}}$ International Molinological Conference met in Cascais (Portugal). The Conference was attended by representatives of molinological societies, museums, research centres and publishing houses from all over Europe. The International Molinological Society was established and the International Molinological Dictionary was drawn up. Such conferences are still organised in different European countries every few years. Each ends with a publication containing all the papers delivered, discussions, the conference programme, and a list of participants with their contact details (Szymański 1990: 290-292).

During the first Molinological Conference in 1965, a new term was coined: molinology, meaning the science of mills. It is a combination of the words molinum (Lat.) and logia (Gr.), and it has been commonly used since then. The science is interdisciplinary and it is concerned with the construction and architectural forms of mills, milling devices, and their functions. It also gathers information about the evolution of mills, hypotheses about their origins, economic and social conditions, terminology, and nomenclature (Szymański I990: 29I).

On February 29, 20I6, inspired by the above events, a Molinological Forum was organised in Jaracz, which included a discussion on the establishment of the Polish Molinological Society, the condition of the milling industry in 
Poland, and the organisation of the so-called Day of Windmills. It was attended by ethnographers, historians, architects, conservator-restorers, mill owners and people interested in the old milling industry. As a result, the first Polish Day of Windmills was organised in 2016 (with the second edition in 20I7), and a website devoted to this event was launched (www.dzienmlynow.pl). In other countries, similar events have been organised for years: in Germany, on Whit Sunday, since 1993; in the Netherlands, at the second weekend of May, since 1973; and in France, in mid-June. There are similar practices in the United Kingdom and Switzerland. Such events offers an opportunity to see mills that are normally unavailable to visitors. Mill owners declare their readiness to take part in the event in advance, and then they give free tours of their mills, talking about the work of a miller. The Day of Windmills generates a great interest both among mill owners and visitors, also in Poland.

It is worth noting that over the last few years more and more initiatives have been launched with the aim to renovate windmills. Many of the buildings were restored between 2007 and 2013 under the Rural Development Programme as part of the 'Renewal and Development of Rural Areas' activity.

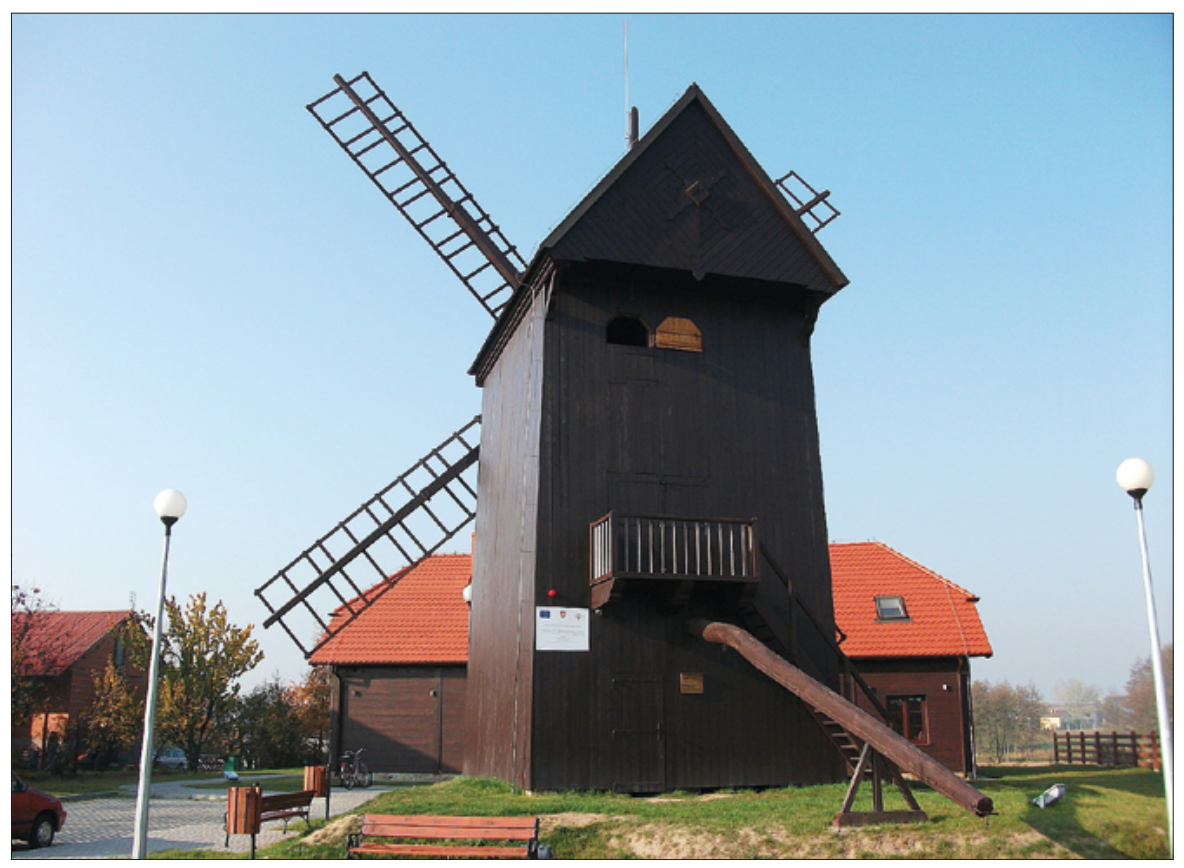

Fig. 2. A post mill in Budzisław Kościelny (Greater Poland Province) (source: http://www. konin.naszemiasto.pl/artykul/wiatraki-kozlak-w-budzislawiu-koscielnym-zdjecia,1948511,artgal,t,id,tm.html, access 20 VI 2017). 
Examples of such activities include windmills in Budzisław Kościelny (Greater Poland Province), Duchowo (Lower Silesia Province), and Dębe (Greater Poland Province).

The windmill in Budzisław Kościelny was built in 1858 , and together with the miller's house it houses the Memorial Room of the Country, Molinology and Agriculture. In 20II, having been renovated, it was made available to visitors. It attracts much interest among the local inhabitants and tourists staying at Budzisławskie Lake (www.konin.naszemiasto.pl/artykul/wiatraki-kozlak-w-budzislawiu-koscielnym-zdjecia,1948511,artgal,t,id,tm.html).

The post mill in Duchowo was built in I67I. The renovation work on the building was performed in 20I0. It is now a venue for meetings of local inhabitants and a tourist attraction for visitors (www. dolny-slaskorg.pl/5274275, Historia_ wiatraka_w_Duchowie.html).

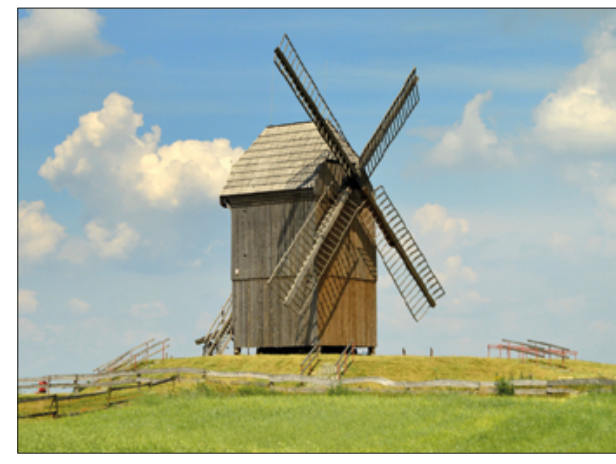

Fig. 3. The post mill in Duchowo (Lower Silesia Province) (source: http://www.dolny-slaskorg. pl/5274275,Historia_wiatraka_w_Duchowie.html, access 20 VI 2017).

The windmill in Dębe dates back to the first half of the $19^{\text {th }}$ century. In 2007, the Commune Office in Lubasz, due to the progressing degradation of the mill, started to apply for funds for its renovation and reconstruction. The preparation took a few years and required considerable effort

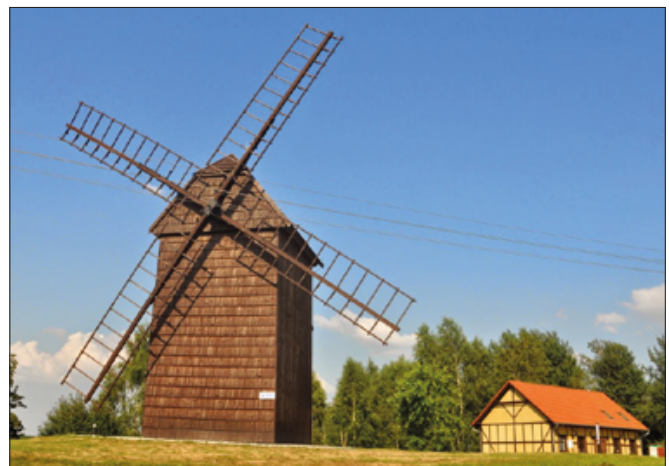

Fig. 4. The post mill in Dębe (Greater Poland Province) (source: http://www.otwartezabytki.pl/pl/ relics/59150-wiatrak-kozlak, access 20 VI 2017). on the part of many employees of the Commune Office in Lubasz and the Commune Community Centre. In 2009, the Commune received a grant from the Marshall's Office for the 'Renewal and Development of Rural Areas' activities under the Rural Development Programme, and at the end of June 2010 the mill was made available to visitors (www.otwartezabytki.pl/pl/ relics/59150-wiatrak-kozlak). 
The open-air museum in Prusim (Greater Poland Province) has achieved a great success as in 2018 it relocated its second windmill: the first one was a smock mill, and the second one - a paltrok mill. The funds for the relocation, renovation and conversion work were received from the Greater Poland Regional Operational Programme for 2OI4-2020. The project aimed to introduce a cultural function and to make the mill available to visitors. On the first storey of the windmill, a film documenting the work connected with the relocation and conservation will be shown, together with a multimedia presentation on the windmill's history. The new cultural object is to be opened and made available in the middle of 2019 (http://www.mapadotacji. gov.pl/projekt/7306or4).

Another smock mill has been adapted in a similar way in Polkowice in the Lower Silesia Province, and was incorporated into a large restaurant and conference centre. However, the mill itself serves a typical museum function. Individual storeys present the history of the town of Polkowice and of the windmill as well as some general information about the miller's trade. The exhibition makes use of modern multimedia technologies including installations, animations, and holograms (https://www.polkowice.eu/news,7805, Odbudowa-wiatraka-coraz-blizej.html). It is worth noting that the project involving conversion of this windmill was developed as part of a thesis in Interior Design written at the Univeristy of Zielona Góra (https://zszywka.pl/p/adaptacja-wiatraka-wiezowego-w-polk-13386095.html), and that there are more and more such practices. This may indicate that young people start to notice the dying architecture and make attempts to use its value so as to create new forms. Students creating conservator's documentation including measurement and drawing inventories, architectural studies, and photographic documentation, contribute to the preservation of these monuments, consolidation of knowledge of them, and creation of a carrier that can be a valuable source of information for the generations to come.

The interest of young people, and particularly architects, in the issue of cultural heritage protection allows to view the problem at hand in realistic and innovative terms. The idea that is more and more frequently promoted in the society is the conversion of old mills and windmills into apartments. Recreation of the original appearance and the use of the windmill's natural qualities can create a very atmospheric and original interior, thus raising the standard of the building and giving it a second life (www.rynekpierwotmy.pl). However, this entails a certain risk. In order to be able to use a mill for residential purposes, some conversion of the object is necessary. What matters is that after the revitalisation the windmill preserves as much of its original form as possible.

A few dozen kilometres from Polkowice, in the town of Radziechów, restoration and adaptation work on the ruin of a masonry smock mill is planned. 
The building is to house a vantage point and an astronomical observatory, which aroused a great interest of the Polish Astronomical Society. The historical windmill is to become a part of the tourist bike trail leading to the Grodno Castle. One of the investors is the Kaczawskie Mountains Partnership - Local Action Group (http://www.radiowroclaw.pl/articles/view/67440/ XIX-wieczny-wiatrak-z-Radziechowa-zostanie-odrestaurowany).

There are also more and more initiatives launched by private mill owners who want to protect the buildings and use them as a source of income. The boarding house in Lędzin (West Pomerania Province) is an interesting undertaking, with an old mill housing hotel rooms. The interior design makes use of the natural qualities of the historical building. The owners make sure that the facility is environmentally-friendly. They installed solar cells on the roof to provide the object with electricity, and there are thermal cells heating water. The owners claim that work related to the mill is their passion (https://gs24.pl/w-wiatraku-lub-na-wodzie/ar/5088798).

In Solca Wielka (Łódź Province), thanks to the financial and substantive support from the Łódź Provincial Monument Conservator, the Ozorków Commune, and the Łódź Province Marshall's Office, a $1^{\text {th }}$-century post mill has been restored. Today, it looks great and it is one of the greatest tourist attractions of the Ozorków Commune. A similar object can be found in the Chodów Commune (Greater Poland Province). It has been restored thanks to the funds from the Greater Poland Province Marshall's Office (Tomaszewski, Walczak 2018: 60). Had it not been for the funds from the communal or provincial budget, such windmills would have probably had no chance of undergoing any renovation. The cost of such work is huge, and private owners simply cannot afford it. Another important issue is the substantive support from the monument preservation services.

Naturally, the mills described above are only a few examples of the good practices closely connected with the protection and renovation of windmills. There are many similar cases. In almost all of them windmills have become cultural centres and have been made available to the broader public. They are frequently visited by the local community and tourists. Even though they no longer serve their original purposes, some of their qualities were deemed worthy of exhibiting, and thus the interest of the public was attracted. The renovated mills have become the trademarks of many communes and towns, inspiring further activities aimed at the protection of other monuments. They are also frequently included in bike trails. More and more people start to appreciate the value of windmills, meaning, of course, the intangible value that is invisible to the eye. It is a very positive factor contributing to an increased interest in these objects not only among those fascinated by the miller's trade, but also ordinary visitors. Naturally, the greatest problem that remains unresolved is the 
obtaining of financial resources for conservation and restoration work. If one meets certain criteria, the available EU projects and programmes may provide financial resources but it is not enough to restore most of the still existing, valuable windmills. Considerable hopes are pinned on the wealthiest part of the society, who would be able to renovate mills and, for example, convert them for residential purposes, as it was already mentioned. The fact that windmills are located on hills, near rivers and meadows, creates perfect conditions for resting, recovering one's strength, communing with nature, and contemplation. Rearrangement of the interior and structure of windmills remains a matter of serious controversy as it entails the risk of erasing the most valuable elements. However, it is necessary in order to convert the building properly, to use its qualities, to partially preserve it, and to give it a second life.

There should be more studies into windmills, younger generations should be made aware of their value, and volunteers should be involved in the promotion of the so-called good practices, which will all improve the state of preservation of these monuments and popularise regional history including the history of the milling industry. Spreading the awareness and developing the understanding of the cultural heritage around us is a lengthy process. There are already some effects, and more will come gradually. The time will show to what extent we managed to protect historical monuments and how many of them will be available to the future generations.

\section{Bibliography}

Adamczewski J. (2005), Mtynarstwo magiczne, Polskie Towarzystwo Ludoznawcze, Wroctaw. Czajkowski J. (2001), Lokalne muzea na wolnym powietrzu w Polsce, "Acta Scansenologica", 8, p. 7-52.

Gola G. (2007), Kraina wiatraków powraca. Materiaty konferencyjne, Klub Nowodworski, Nowy Dwór Gdański.

Gosztyła M., Pasztor P. (2013), Konserwacja i ochrona zabytków architektury, Oficyna Wydawnicza Politechniki Rzeszowskiej, Rzeszów.

Grabski J. (2012), Ochrona budownictwa drewnianego, Księgarnia Akademicka, Kraków. Jasiuk J. (1965), Aktualne problemy ochrony zabytków techniki w Polsce, "Ochrona Zabytków", 18 (3), p. 3-12.

Klajmon B., Liboska T. (2013), Ogólny program konserwatorkki. Rewitalizacja wiatraka z Grzawy posadowionego na terenie muzeum Górnoślaski Pak Etnograficzny, Chorzów (a manuscript). 
Kowaleski J. (1972), Problemy organizacji i budowy Opolskiego Parku Etnograficznego w Bierkowicach, "Opolski Rocznik Muzealny”, 5 (1), p. 421-452.

Kozłowski K. (2010), Tu między paltraki wtaża gotoszyjki, "Posłaniec Warmiński”, 34/28, p. IV-V.

Kraszewska-Sikorska E. (2008), Rola Kujawsko-Dobrzyńskiego Parku Etnograficznego w przekazywaniu dziedzictwa kulturowego regionu, "Rocznik Muzealny", 12 (1), p. 171-184.

Kudła A. (1969), Stan i propozycje ochrony budownictwa ludowego w województwie katowickim, "Materiały Muzeum Budownictwa Ludowego w Sanoku”, 10, p. 26-30.

Midura F. (1979), Muzealnictwo skansenowskie w Polsce (stan obecny i perspektywy rozwoju), [in:] F. Midura (ed.), Muzea skansenowskie w Polsce, Państwowe Wydawnictwo Rolnicze i Leśne, Poznań, p. 28-48.

Nowakowski C. (2006), Wiatraki Pomorza Zachodniego: http://www.bdz.szczecin.pl/ images/stories/publikacje/wiatraki_pomorza_zachodniego.pdf (access 20 VI 2017).

Pawlik M. (1984), Wiatraki pótnocno-wschodniej Polski, Dział Wydawnictw Filii UW, Białystok.

Prarat M. (2011), O potrzebie badań ciesielskich konstrukcji mtynów wietrznych na przyktadzie prac konserwatorskich przy koźlaku z Bierzgtowa na ziemi chetmińskiej, "Wiadomości Konserwatorskie", 30, p. 94-104.

Prarat M. (2015), Próba zarysowania specyfiki badań architektonicznych budowli drewnianych na przyktadzie analizy substancji i struktury wieńcowych chatup podcieniowych na obszarze Dolnej Wisty, [in:] M. Arszyński, M. Prarat, U. Schaaf, B. Zimnowoda-Krajewska (ed.), Badania architektoniczne. Historia i perspektywy rozwoju, Wydawnictwo “Bernardinum”, Toruń, p. 183-210.

Ptaśnik M. (1969), Rozwój i osiagnięcia muzeów budownictwa ludowego w XXV-leciu PRL, "Materiały Muzeum Budownictwa Ludowego w Sanoku”, 10, p. 7-10.

Reinfuss R. (1976), Spoteczna i dydaktyczna rola muzeów na wolnym powietrzu, "Materiały Muzeum Budownictwa Ludowego w Sanoku”, 21, p. 7-12.

Rouba B. (2000), Czy użytkownik może zagrażać zabytkowi?, [in:] J. Sosnowska (ed.), III Forum Konserwatorów. Dobra kultury w obliczu zagrożeń, Urząd Wojewódzki. Wydział Ochrony Środowiska, Toruń, p. 49-57.

Stefański S. (1969), Cele i osiagnięcia Muzeum Budownictwa Ludowego w Sanoku w latach 1958-69, "Materiały Muzeum Budownictwa Ludowego w Sanoku”, 10, p. 20-25.

Stokhuyzen F. (2010), De Hollandsche Molen. Vereniging tot behoud van molens in Nederland, Algemene Vergadering van De Hollandsche Molen, Amsterdam.

Szymański A. (1990), V Międzynarodowe Sympozjum Molinologiczne, "Acta Scansenologica”, 6, p. 290-303.

Święch J. (1986), Skansen Kujaw i Ziemi Dobrzyńskiej w Któbce, "Acta Scansenologica”, 4, p. 179-200. 
Tajchman J. (2007), Metoda konserwacji i restauracji dziedzictwa architektonicznego w zakresie zabytkowych budowli, [in:] A. Kociałkowska (ed.), Konserwacja i ochrona zabytków architektury, Europejska Fundacja Ochrony Zabytków, Studzienka, p. 35-57.

Tomaszewski F., Walczak B. (2018), Eęczyckie wiatraki - inicjatywy konserwatorskie z lat 2006-2017 na przyktadzie „Zagrody Mtynarskiej” w Uniejowie, "Budownictwo i Architektura", 17 (1), p. 55-61.

Uszyńska A. (2009), Muzea skansenowskie szansa na zachowanie wartości kulturowej wiejskiej architektury drewnianej na potudniowo-zachodnim Podlasiu, "Ciechanowiecki Rocznik Muzealny”, 5, p. 69-93.

Uszyński K. (1978), Formy spotecznego zagospodarowania zabytkowych mtynów i wiatraków, "Materiały Muzeum Budownictwa Ludowego w Sanoku", 24, p. 33-38.

\section{Online Sources}

The Day of Windmills: http://www.dzienmlynow.pl (access 20 VI 2016). http://www.mapadotacji.gov.pl/projekt/7306014 (access 15 II 2019). http://www.radiowroclaw.pl/articles/view/67440/XIX-wieczny-wiatrak-z-

Radziechowa-zostanie-odrestaurowany (access 15 II 2019). http://www.radziejow.pl/372,gmina-topolka.html (access 4 VI 2017). https://gs24.pl/w-wiatraku-lub-na-wodzie/ar/5088798 (access 15 II 2019). https://www.polkowice.eu/news,7805,Odbudowa-wiatraka-coraz-blizej.html (access 15 II 2019).

https://zszywka.pl/p/adaptacja-wiatraka-wiezowego-w-polk-13386095.html (access 15 II 2019).

Konin. Nasze Miasto: http://www.konin.naszemiasto.pl/artykul/wiatrakikozlak-w-budzislawiu-koscielnym-zdjecia,1948511,artgal,t,id,tm.html (access 20 VI 2017).

National Heritage Board of Poland: http://www.nid.pl/pl/Informacje_ogolne/ Zabytki_w_Polsce/rejestr-zabytkow/zestawienia-zabytkow-nieruchomych/ Raport_o_stanie_zabytkow_2004.pdf (access 20 VI 2017).

Otwarte Zabytki: http://www.otwartezabytki.pl/pl/relics/59150-wiatrak-kozlak (access 20 VI 2017).

http://www.dolny-slaskorg.pl/5274275,Historia_wiatraka_w_Duchowie.html http://www.rynekpierwotmy.pl (access 15 II 2019) 


\title{
Summary
}

Windmills as the Forgotten Cultural Heritage Returning to Favour

Windmills are extremely interesting examples of architectural and technological monuments. For years, the objects located in Poland were neglected and their degradation was very rapid. There were many factors that contributed to this situation including unprofitable production, the ageing of staff, lack of successors, and insufficient financial resources of provincial conservators for the co-funding of conservation and restoration projects. Over the past few years, the number of initiatives, patterned on foreign practices, have been growing. Their aim is to preserve and popularise windmills. In many cases, windmills are converted into hotels or apartments.

Keywords: windmill, mill, conservation protection, monument

\section{Streszczenie}

\section{Młyny wietrzne jako zapomniane dziedzictwo kulturowe powracające do łask}

Wiatraki są niezwykle ciekawym przykładem zabytków architektury i zabytków techniki. Przez lata obiekty zlokalizowane na terenie Polski były zaniedbywane, a ich degradacja postępowała szybko. Przyczyniło się do tego wiele czynników, m.in. nieopłacalność produkcji, starzenie się kadry pracowniczej i brak jej następców, niewystarczające środki finansowe wojewódzkich konserwatorów zabytków na dofinansowanie prac konserwatorskich i restauratorskich. W ciągu kilku ostatnich lat, na wzór działań zagranicznych, zaczyna pojawiać się coraz więcej inicjatyw, których celem jest zachowanie i ochrona jak największej liczby młynów wietrznych oraz ich popularyzacja. Częstym zjawiskiem jest aranżowanie wiatraków na hotele lub do celów mieszkalnych.

Słowa kluczowe: wiatrak, młyn, ochrona konserwatorska, zabytek

\author{
Emilia Habecka-Rosiak \\ Provincial Office of Monument Preservation in Poznań \\ e-mail: emiliahabecka1991@gmail.com
}

